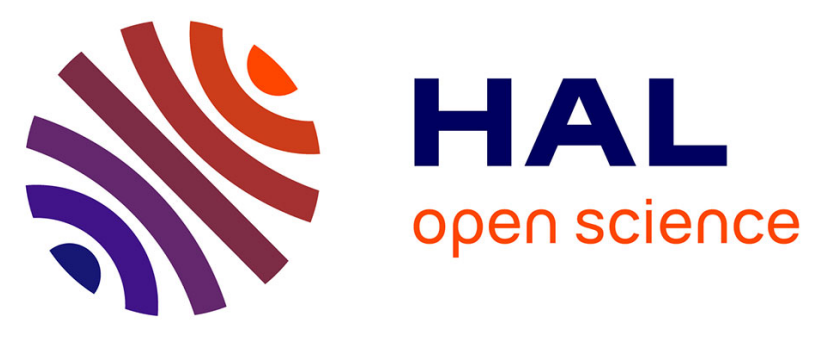

\title{
VISCERAL LEISHMANIASIS IN HEMOGLOBINOPATHY PATIENT WITH COMPLICATION FROM GLUCANTIME® USE: DIAGNOSTIC AND THERAPEUTIC CHALLENGE
}

Gustavo Carneiro Resstel, Mara Regina Avelino de Paula, Rafael Ramalho Vale Cavalcante, Ana Beatriz Moraes de Abreu Salgado, Johnatan Michael Fernandes de Souza, Mariana Cotrim Brasil Videira Delbello, Natália Cristina Alves, Carlos Alberto Rodrigues Junior, Calixto Ismael Diaz Libera

\section{- To cite this version:}

Gustavo Carneiro Resstel, Mara Regina Avelino de Paula, Rafael Ramalho Vale Cavalcante, Ana Beatriz Moraes de Abreu Salgado, Johnatan Michael Fernandes de Souza, et al.. VISCERAL LEISHMANIASIS IN HEMOGLOBINOPATHY PATIENT WITH COMPLICATION FROM GLUCANTIME® USE: DIAGNOSTIC AND THERAPEUTIC CHALLENGE. Revista de Patologia do Tocantins, 2018, 2018, 5 (3), pp.37-43. 10.20873/uft.2446-6492.2018v5n3p37 . hal-03218156

\section{HAL Id: hal-03218156}

https://hal-mines-paristech.archives-ouvertes.fr/hal-03218156

Submitted on 5 May 2021

HAL is a multi-disciplinary open access archive for the deposit and dissemination of scientific research documents, whether they are published or not. The documents may come from teaching and research institutions in France or abroad, or from public or private research centers.
L'archive ouverte pluridisciplinaire HAL, est destinée au dépôt et à la diffusion de documents scientifiques de niveau recherche, publiés ou non, émanant des établissements d'enseignement et de recherche français ou étrangers, des laboratoires publics ou privés. 


\section{VISCERAL LEISHMANIASIS IN HEMOGLOBINOPATHY PATIENT WITH COMPLICATION FROM GLUCANTIME ${ }^{\circledR}$ USE: DIAGNOSTIC AND THERAPEUTIC CHALLENGE}

\section{LEISHMANIOSE VISCERAL EM PACIENTE PORTADORA DE HEMOGLOBINOPATIA COM COMPLICAÇÃO POR USO DE GLUCANTIME ${ }^{\circledR}$ : DESAFIO DIAGNÓSTICO E TERAPÊUTICO}

\begin{abstract}
Gustavo Carneiro Resstel ${ }^{1}$, Mara Regina Avelino de Paula ${ }^{1}$, Rafael Ramalho Vale Cavalcante ${ }^{1}$, Ana Beatriz Moraes de Abreu Salgado ${ }^{2}$, Johnatan Michael Fernandes de Souza ${ }^{2}$, Mariana Cotrim Brasil Videira Delbello ${ }^{3}$, Natália Cristina Alves $^{2}$, Carlos Alberto Rodrigues Junior ${ }^{1}$, Calixto Ismael Diaz Libera ${ }^{4}$.
\end{abstract}

\begin{abstract}
Visceral Leishmaniasis (VL) is a chronic, severe and systemic protozoonosis caused by different species of the genus Leishmania sp., which results in death in $90 \%$ of cases if not treated. Clinical suspicion should be raised when the patient has fever and splenomegaly, associated or not with hepatomegaly. This paper presents the case report of a patient admitted to Dona Regina Siqueira Campos Maternity Hospital, in Palmas, Tocantins, Brazil, with a clinical history of thrombocytopenia and splenomegaly, initially diagnosed and treated as a VL, but later diagnosed with SC Hemoglobinopathy. During pregnancy, women with HbSC genotype may develop complications as severe as those presented by women with HbSS genotype. However, the symptoms presented by this patient at the end of gestation may also be confused with the VL condition, a diagnosis for which she presented two positive laboratory tests.
\end{abstract}

Keywords: Visceral Leishmaniasis, Hemoglobinopathy SC, Glucantime ${ }^{\circledR}$.

Citação: Resstel GC, Paula MRA, Cavalcante RRV, Salgado ABMA, Souza JMF, Delbello MCBV, Alves NC, Rodrigues Junior CA, Libera CID (2018) Visceral Leishmaniasis in hemoglobinopathy patient with complication from Glucantime $^{\circledR}$ use: diagnostic and therapeutic challenge. Revista de Patologia do Tocantins, 5(3): 37-43.

Instituição: ${ }^{1}$ Médico, Graduado pela Universidade Federal do Tocantins (UFT), Tocantins, Brasil. ${ }^{2}$ Acadêmico(a) de Medicina, Centro Universitário de Gurupi (Unirg), Tocantins, Brasil; ${ }^{3}$ Acadêmico(a) de Medicina, Universidade Federal do Tocantins, Tocantins, Brasil; ${ }^{4}$ Médico, Especialista em Hematologia, Hospital Geral Público de Palmas (HGPP), Tocantins, Brasil.

Autor correspondente: Gustavo Carneiro Resstel; gustavo.c.resstel@gmail.com

Editor: Guedes V. R. Medicina, Universidade Federal do Tocantins, Brasil.

Publicado: 09 de setembro de 2018.

Direitos Autorais: (c) 2018 Resstel et al. Este é um artigo de acesso aberto que permite o uso, a distribuição e a reprodução sem restrições em qualquer meio, desde que o autor original e a fonte sejam creditados.

Conflito de interesses: os autores declararam que não existem conflitos de interesses.

\begin{abstract}
RESUMO
A leishmaniose visceral (LV) é uma protozoonose de evolução crônica, grave e sistêmica, causada por diferentes espécies do gênero Leishmania sp., que resulta em morte em $90 \%$ dos casos se não tratada. A suspeita clínica deve ser levantada quando o paciente apresentar febre e esplenomegalia associada ou não à hepatomegalia. Apresentamos, neste trabalho, o relato de caso de uma paciente que deu entrada no Hospital e Maternidade Dona Regina Siqueira Campos (HMDR), em Palmas, Tocantins (TO), com quadro de plaquetopenia e esplenomegalia e inicialmente diagnosticada e tratada como um quadro de LV e posteriormente diagnosticada com Hemoglobinopatia SC. Durante a gestação, mulheres portadoras do genótipo $\mathrm{HbSC}$ podem desenvolver complicações tão graves quanto as apresentadas por mulheres portadoras do genótipo $\mathrm{Hb}$ SS. No entanto, os sintomas apresentados pela paciente ao final da gestação podem ser confundidos também com o quadro de LV, diagnóstico para o qual apresentou dois exames laboratoriais positivos.
\end{abstract}

Palavras-chave: Leishmaniose visceral, Hemoglobinopatia SC, Glucantime ${ }^{\circledR}$. 


\section{INTRODUCTION}

Visceral Leishmaniasis (VL), or kalazar, was first described in Greece, in 1835, and later in India, in 1882. At that time, emphasis was placed on skin darkening, a typical aspect of the disease found in India, that usually did not manifest in Brazil. This characteristic formed the basis of the first denomination of this disease, which was called "black fever", "kala-jwar" or "kalazar" by the Indians. In 1903, Laveran and Mesnil identified the parasite in material supplied by Leishman and Donovan. In Leishman's honor, the disease associated with this parasite was denominated Leishmaniasis, which is the most commonly used terminology in Western countries. ${ }^{1,2}$

$\mathrm{VL}$ is a protozoonosis, characterized by a severe and systemic chronic evolution, caused by different species of the genus Leishmania sp., that results in death in $90 \%$ of cases if not treated. In the Americas, the disease's etiological agent is L. (L.) chagasi. ${ }^{3,4}$ Once characterized as an eminently rural zoonosis, the disease has undergone changes and has become a public health problem as it expanded to urban areas of medium and large size, throughout Brazilian territory, especially in the 1980s and 1990s. ${ }^{5}$ VL's incidence is increasing in urban areas, demonstrating the adaptive capacity of the vector to environments modified by men, which also suggests human action as an important factor in the spread of the epidemic. $^{6}$

VL is considered a neglected disease by the World Health Organization (WHO). It caused more deaths in Brazil between 2000 and 2011 than dengue and malaria, occupying the third place in terms of mortality among neglected diseases, that is, those that affect mostly people living in poverty, without adequate sanitation, and in close contact with infectious vectors. ${ }^{7,8}$

This zoonosis is present in all continents, in more than 60 countries. However, more than $90 \%$ of registered cases are concentrated in only 6 of them: India, Bangladesh, Sudan, South Sudan, Brazil and Ethiopia. ${ }^{9}$ WHO estimates that 500,000 new cases and 59,000 deaths occur worldwide every year. ${ }^{10}$ In Brazil, VL has autochthonous cases in $25 \%$ of municipalities, in 21 of its 26 states. ${ }^{8}$ According to the Ministry of Health, in 2015, the Tocantins (TO) state had the highest incidence among Brazilian states, with 12.2 cases / 100,000 inhabitants. ${ }^{11}$

In Tocantins, urbanization of the vector and spread of the disease has taken place due to ecological changes caused by the entry of men into wild sites, such as: the construction of the state's capital; interest in activities related to the penetration of forests; common habits among the population, like raising animals in backyards or urban streets; the intense migratory flow; and the lack of basic sanitation structure. ${ }^{12}$

In urban areas, the dog (Canis familiaris) is the main reservoir of VL, while in the wild, foxes (Dusicyon vetulus and Cerdocyon thous) and marsupials (Didelphis albiventris) are the main source of infection. The disease is transmitted through blood-sucking insects infected with Leishmania (L.) chagasi. In Brazil, two species are related to the transmission: the main one, Lutzomyia longipalpis; and Lutzomyia cruzi, specificly in areas of Mato Grosso and Mato Grosso do Sul states. The possibility of a third species (Lutzomyia migonei) being involved in the transmission is still studied due to its high density in sites with absence of $L$. longipalpis and/or $L$. cruzi and autochthonous cases of the disease. ${ }^{13}$

Clinical suspicion should be raised when a patient presents with fever and splenomegaly, associated or not with hepatomegaly. ${ }^{14}$ In Brazil and worldwide, there are few reports of VL in pregnant women and, between those available, the cases originate from regions known to be endemic for the disease. ${ }^{15}$ However, with the spread of the disease between urban and peri-urban areas in Brazil, where adults were generally not exposed to Leishmania sp., cases of pregnant women with VL have already been reported. ${ }^{16}$

This paper reports the case of a patient who was admitted to the Hospital e Maternidade Dona Regina Siqueira Campos (HMDR), in Palmas / TO, with a clinical history of thrombocytopenia and splenomegaly, initially diagnosed and treated as VL.

\section{CASE REPORT}

S. N. S., female, 36 years old, she was gravida 3 para 2 having had two previous cesarean deliveries and none miscarriage, brown, in a stable union, coming from Taguatinga / TO. She was referred to HMDR, in Palmas / TO, with 38 weeks of gestation (calculated by ultrasonography (USG) of 15 weeks and 4 days) for obstetric evaluation due to thrombocytopenia. She had received adequate prenatal care. The patient reported that in a previous pregnancy, she presented the same clinical scenario at the end of gestation. She reports that, at the time, she gave birth to a stillborn fetus via cesarean delivery. She denied comorbidities or continuous use of medications, but claimed a family history of sickle cell anemia (sibling).

At hospital admission, the patient complained of asthenia and reported having long-standing thrombocytopenia and anemia, with unknown cause. At physical examination, she was pale $(+/ 4+)$, icteric $(+/ 4+)$, hydrated, eupneic, and hemodynamically stable. A palpable spleen, $6 \mathrm{~cm}$ below the left costal border, was detected. USG showed an increased spleen, measuring approximately $19 \times 14$ $x 7 \mathrm{~cm}$. Doppler flow of the umbilical artery within normality.

In laboratory tests from admission, hemoglobin (Hb): $10.6 \mathrm{~g} / \mathrm{dl}$; hematocrit (Ht): 30.9\%; leukocytes: 9,980 / $\mathrm{mm}^{3}$; platelets: $86,000 / \mathrm{mm}^{3}$; clotting time (CT): 5 minutes; bleeding time (BT): 1.30 minutes; prothrombin time (PT): 12.20 seconds; INR: 0.90; active partial thromboplastin time (APTT): 30 seconds; urea: $21.0 \mathrm{mg} / \mathrm{dl}$; creatinine: $0.7 \mathrm{mg} / \mathrm{dl}$; alanine aminotransferase (ALT): $14 \mathrm{U} / \mathrm{L}$; aspartate aminotransferase (AST): $26 \mathrm{U} / \mathrm{L}$; urinalysis: no alterations.

Eight hours after admission to the maternity ward, the obstetric team's decision was to perform a cesarean delivery. There were no intercurrences during the surgery, and a term newborn, adequate to gestational age, was delivered in good vitality. 


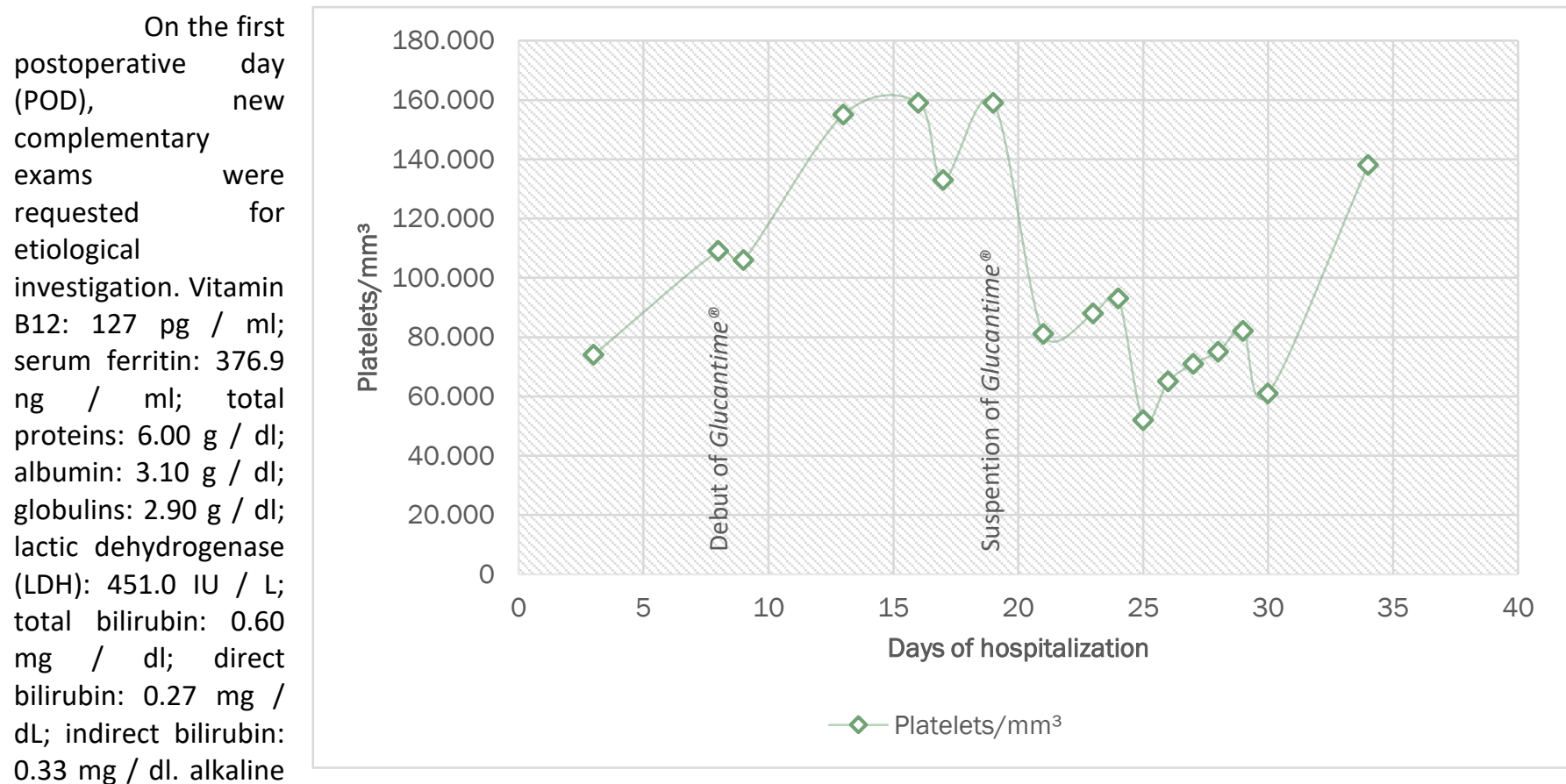

$0.33 \mathrm{mg} / \mathrm{dl}$. alkaline

phosphatase $110 \mathrm{U} / \mathrm{L}$; gamma glutamyl transferase (GGT): $15.0 \mathrm{U} / \mathrm{L}$.

Five days after delivery, the presence of phlogistic signs and bulging in the incision site were noted. Antibiotic therapy with Cefalotine 1g, 6 / 6h, was initiated. An USG of the region showed laminar net collections along the surgical scar, related to seroma. The exit of purulent secretion through the operative wound (OW) was observed, and manual drainage was performed.

On the 7th day of hospitalization, a rapid test for Leishmania sp. (Kala-azar Detect ${ }^{\circledR}$ ) showed a positive result. Indirect Immunofluorescence Serology for Human Visceral Leishmaniasis (IgG), collected in the 1st POD, was reagent, title 1:80. With the results of rapid test and serology, treatment for $\mathrm{VL}$ with Meglumine Antimoniate (Glucantime ${ }^{\circledR}$ ), $14.8 \mathrm{ml}$ intravenous (EV), once daily (20 $\mathrm{mg} \mathrm{Sb}^{+5} / \mathrm{kg} /$ day) was started. She completed 8 days of Cefalotine, at the 12 th POD, with improvement of phlogistic signs in the OW, but persistent seroma output. Dressing was performed three times a day, with vigorous expression of the wound and progressive decrease of secretion.

She evolved with no further complaints and important improvement of the overall scenario. Breastfeeding was discontinued due to use of Glucantime ${ }^{\circledR}$, in accordance to pediatrics' and infectlogist's recommendations.

At the beginning of treatment for $\mathrm{VL}$, an evaluation from the infectious disease service was requested, which occurred on the fifth day of treatment. Since the patient did not present clinical and laboratory findings compatible with VL (no fever, no AST / ALT alterations, and no leucopenia), it was decided to carry out a direct bone marrow search for diagnostic confirmation. On the sixth day of treatment, after reviewing the medical record and the direct search for Leishmania $s p$. in the bone marrow, the infectious team considered that the patient did not present a clinical picture compatible with VL. Suspension of Glucantime ${ }^{\circledR}$ and release of breastfeeding were recommended.

However, due to observation of significant clinical and laboratory improvement, with an expressive increase in

platelet count (Graphic 1) and considering that the myelogram was performed in an inopportune time, the HMDR medical team insisted on the diagnosis of $\mathrm{VL}$ and opted for treatment until the tenth day. On the tenth day of treatment for $V L$, the patient presented general malaise and dyspnea on minimal exertion. Laboratory tests showed severe anemia, with $\mathrm{Hb} 4.7$ g / dL, Ht: 14.6\%. Four red blood cells concentrates were transfused and Glucantime ${ }^{\circledR}$ treatment was suspended.

Three days after Glucantime ${ }^{\circledR}$ withdrawal, on the 22nd caesarean section POD, she was admitted to the emergency room of the Hospital Geral Público de Palmas (HGPP), with severe fatigue, malaise, arthralgia and fever sensation. At physical examination she was lucid, oriented, Glasgow Coma Scale (GCS 15), dehydrated $3+/ 4+$, hypoxemic $2+/ 4+$, anicteric, afebrile. She presented dyspnea at minimal efforts, in use of $\mathrm{O} 2$ under mask at 5 liters / min. Blood Pressure: 156x82 mmHg. Heart Rate: 56-77 bpm. Abdomen: globose, distended, painful at palpation on the left hypochondrium, with splenomegaly of approximately $7 \mathrm{~cm}$ below the left costal border, hepatomegaly $2 \mathrm{~cm}$ below the right costal border. Cardiovascular and respiratory systems showed no alterations.

Electrocardiogram revealed sinus bradycardia, with a heart rate of $40 \mathrm{bpm}$. Evaluation from cardiology and hematology services, as well as laboratory tests and chest Xray were requested. Sepsis protocol was initiated (Ceftriaxone $1 \mathrm{~g} \mathrm{EV} 12$ / 12h and Clindamycin 600mg EV 8/8h) and a spot in the Intensive Care Unit (ICU) was requested.

The patient presented a normal echocardiogram, with an ejection fraction of $73 \%$. Cardiotoxicity due to use of Glucantime $^{\circledR}$ was suspected, restriction of cardiotoxic medications was recommended. In the 23rd postoperative day, she was admitted to the adult ICU, where she received transfusion of two phenotyped red blood cell concentrates, two fresh frozen plasma concentrates and two platelet concentrates due $\mathrm{Ht}$ : 18.4\%, Hb $5.2 \mathrm{~g} / \mathrm{dL} ; 93.000 / \mathrm{mm}^{3}$ platelets; PT of 12 seconds; RNI 0.97 and APTT of 25 seconds. 
She was discharged from the ICU to the clinic ward after 5 days, where she finished an antibiotic regimen (10 days) and maintained hepatosplenomegaly without abdominal pain.

She was evaluated by the Hematology team and received the diagnosis of Hemoglobinopathy SC. Hemoglobin electrophoresis showed $\mathrm{Hb}$ A2/C/E 33.2\%; $\mathrm{Hb}$ S/D/G 34.2\%; $\mathrm{HbF} 0.3 \%$ and $\mathrm{HbA} 32.2 \%$. Peripheral blood smear was also evaluated (Picture 1).

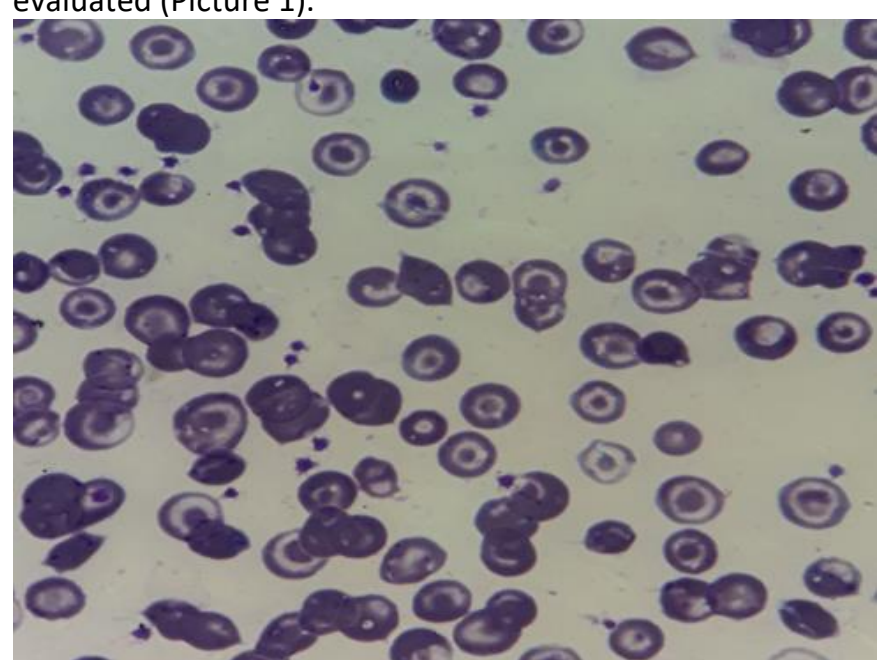

Picture 1: Peripheral blood smear showing target red blood cells. Microscopy performed at the hematology department of the Hospital Geral Público de Palmas (HGPP).

The patient evolved with clinical improvement and no complaints, maintaining hepatosplenomegaly and bicytopenia. She was discharged with prescription of folic acid and acetaminophen in case of pain. She was referred to the HGPP hematology outpatient clinic.

\section{DISCUSSION}

Differential diagnosis among the various causes of thrombocytopenia is a challenge in clinical practice. Splenic aspirate is considered the most sensitive VL's diagnostic method $(96.4 \%)$, followed by bone marrow aspirate $(70.2 \%)$. Serological tests are indirect methods of parasite detection. They precede parasitological evaluation because of their practicality. However, indirect immunofluorescence (IIF) may cross-react with antigens from other organisms. ${ }^{17}$

\section{WRONG DIAGNOSIS OF VL?}

VL is a very serious systemic infection that affects internal organs, such as the spleen, liver, bone marrow and lymph nodes. Clinical features include prolonged fever, fatigue, weight and appetite loss, and hepatosplenomegaly. ${ }^{18}$ In both clinical and control programs, diagnosis of VL remains a challenge. The parasitological diagnosis requires microscopic demonstration of Leishmania sp. amastigotes in tissue biopsy specimens. The most sensitive tissue biopsy specimen for detecting amastigotes is the splenic aspirate, but this procedure carries the risk of fatal hemorrhage. Biopsy samples from other tissues, such as bone marrow or lymph nodes, are associated with fewer risks, but their sensitivities are substantially lower. Alternative diagnostic procedures are serological diagnosis ${ }^{19-22}$ and nucleic acid amplification, such as
PCR techniques. ${ }^{23-24}$ Although PCR seems reasonably sensitive and specific for detection of Leishmania sp. infections ${ }^{23}$, not only is this technology difficult to apply, it has not yet been standardized for practical conditions. In addition, in areas of endemicity, PCR may be very sensitive in clinical scenarios, as it detects many asymptomatic infections. ${ }^{25}$ Several serological tests, such as immunofluorescence and enzyme-linked immunosorbent assay (ELISA), have been used for many years in laboratories, but it was not until the development of the direct agglutination test in the 1980s that the serological diagnosis became feasible in practical settings. ${ }^{26,27}$

In this report, the rapid test used for detection of Leishmania $s p$. was the Kala-azar Detect ${ }^{\circledR}$ test, whose result was positive. A study conducted by Peruhype-Magalhães and colleagues ${ }^{28}$, compared the performance of two rapid tests (Kala-Azar Detect ${ }^{\circledR}$ and IT-LEISH ${ }^{\circledR}$ ) and a serological test (IFI$\mathrm{LH}^{\circledR}$ ) for the diagnosis of VL. Sensitivity values were similar for both rapid tests, but the specificity and positive predictive value of IT-LEISH ${ }^{\circledR}$ were higher than the corresponding values for IFI-LH ${ }^{\circledR}$. Both rapid tests showed satisfactory performance and can then be used in primary health care settings; however, IT-LEISH ${ }^{\circledR}$ allows the use of whole blood samples, making it more suitable for the diagnosis of the disease.

In our patient, a second test, the IIF serology for Human Visceral Leishmaniasis (IgG), showed a positive result of $1: 80$. It was collected in the 1st POD, when treatment with Meglumine Antimoniate (Glucantime ${ }^{\circledR}$ ) was started.

A study conducted by Silveira and colleagues $^{29}$ included VL patients whose diagnosis were confirmed using clinical-epidemiological, serological or parasitological criteria and who were admitted and prescribed for treatment with Glucantime $^{\circledR}$. Clinical and epidemiological diagnosis were considered for patients who had fever and hepatosplenomegaly and were native from regions considered endemic. In this study, all 89 patients underwent a parasitological diagnosis of bone marrow aspirate. Of this total, 68 (76.40\%) were positive and 21 (23.60\%) were negative. Among those who were negative in bone marrow aspirate, three were confirmed by the IIF immune method, while the others were treated based on clinical and epidemiological criteria.

Another study carried out in Madrid, Spain, confirmed the diagnosis predominantly by bone marrow aspirate in $77 \%$ of the patients in included in the research. According to these results, the diagnosis of $\mathrm{VL}$, based on the finding of the parasite in the aspirate of bone marrow aspirate continues to be the diagnostic test carried out in the area. But it is important to understand that even a direct parasitological test may present false negatives, as was the case of our patient ${ }^{30}$, according to the consideration given by the infectious disease service (that the patient did not have a diagnosis compatible with $\mathrm{VL}$ ).

In a study whose objective was to elucidate the clinical, epidemiological and biological profile of $V L$ in children hospitalized at the Infantile Hospital of Rabat, while proving the contribution of serology in the diagnosis of this disease, showed results that confirm that the triad - splenomegaly, pallor and fever - is a good diagnostic element, while the detection of the parasite in the bone marrow continues to be 
the best way to establish the positive diagnosis of this disease. ${ }^{31}$

Tato and colleagues ${ }^{30}$ retrospectively reviewed the medical records of children diagnosed with $V L$ between January 1994 and December 2007, in a tertiary hospital in southern Madrid. The diagnosis of VL was based on the visualization of Leishmania $s p$. in bone marrow aspirate or culture, or positive PCR analysis of bone marrow aspirate. Aspiration was performed in all patients. Microscopic examination of the aspirate detected the presence of intracellular amastigotes in $73 \%$ of cases. The presence of parasite DNA was detected in all cases. The IIF titers were greater than $1: 40$ at the time of diagnosis in $63 \%$ of cases. The determination of the parasite antigen in the urine was positive in 4 of 6 patients (67\%). 3 patients were treated with N-methyl Glucamine Antimoniate and 8 patients (73\%) with Liposomal Amphotericin B. An early clinical response was observed in all patients. These results show how the polymerase chain reaction technique in the aspirate of bone marrow presented greater sensitivity than traditional techniques. However, it is important to note that noninvasive techniques may also be useful in patients with compatible clinical symptoms.

In our case, the HMDR medical team chose to maintain VL treatment up until the tenth day because of the significant clinical improvement presented by the patient and given that the myelogram was considered to have been performed in an inopportune time. We understand that the conduct in this case has been scientifically supported, since the direct research of the parasite in bone marrow aspirate can be negative, while the polymerase chain reaction of this material would be the ideal diagnostic technique, since it presents greater sensitivity.

\section{GLUCANTIME $^{\circledR}$ AND BREASTFEEDING}

The use of Glucantime ${ }^{\circledR}$ for the treatment of $V L$ in women who are breastfeeding is controversial. In the drug's leaflet, it is noted that due to lack of studies, the use of this medication is not recommended during pregnancy. But the physician must weigh the benefit of both treatment and breastfeeding. ${ }^{32}$

However, in the Visceral Leishmaniasis Surveillance and Control Manual, it is stated that there is no contraindication of Glucantime ${ }^{\circledR}$ during breastfeeding. ${ }^{33}$ In the reported case, the medical team chose to discontinue breastfeeding during treatment with Glucantime ${ }^{\circledR}$, backed by the drug leaflet.

\section{GLUCANTIME ${ }^{\circledR}$ CARDIOTOXICITY}

Glucantime $^{\circledR}$ is considered relatively safe and effective in the treatment of VL. However, it is related to some adverse effects, such as arthralgia, myalgia, anorexia, nausea, vomiting, abdominal pain, headache, dizziness, palpitations, hepatic, renal and pancreatic dysfunctions, as well as abnormalities in the electrocardiogram at rest. ${ }^{35}$

The cardiotoxicity of Glucantime ${ }^{\circledR}$ is mainly due to alterations in the electrocardiogram, such as changes in the $T$ wave, a long QT interval, and bradycardia. ${ }^{36}$ In this case, the patient presented symptomatic bradycardia associated with the use of Glucantime ${ }^{\circledR}$.
Cardiotoxicity is directly proportional to the dose and the time of treatment. ${ }^{37}$ Although electrocardiographic changes are not frequent and, when they occur, tend to be reversible, there is a significant potential for morbimortality, as evidenced by reports of sudden death associated with the use of this drug. ${ }^{35}$ Therefore, patients using this medication require rigorous electrocardiographic monitoring. ${ }^{36}$

\section{HEMOGLOBINOPATHY SC}

Hemoglobin SC disease (HbSC) is the most frequent hemoglobinopathy after sickle cell anemia. It occurs when the individual inherits a $B C$ gene for hemoglobin $C$ from one parent and the $\beta S$ gene for hemoglobin $S$ from the other. $\mathrm{HbSC}$ red blood cells contain equal levels of $\mathrm{HbS}$ and $\mathrm{HbC}$ and the blood smear of these individuals contains mainly target cells with few sickle cells. ${ }^{38}$

Medical advances in the last decades, with the introduction of new therapies, have been responsible for increasing the life expectancy of these patients, but management of this disease during pregnancy and puerperium continues to be a great challenge. ${ }^{39}$

Non-pregnant women with SC hemoglobinopathy, a less severe clinical form, may be asymptomatic or oligosymptomatic; however, during pregnancy, they may develop complications as severe as those presented by women with the HbSS genotype, which is explained by physiological changes during this period. ${ }^{40}$

Studies have already shown an increased mortality rate among these pregnant women, especially in the third trimester, as well as among women in puerperium. ${ }^{39}$ It is known that there is a 10 to $15 \%$ increase in plasma volume between the sixth and twelfth week of gestation and between 30 and 34 weeks, when a faster and more significant increase occurs, which induces a modest decrease in hemoglobin levels during gestation. ${ }^{41}$ Other physiological changes capable of justifying the increase of theses patients' morbidity and mortality in the third trimester and in the puerperium are: hypercoagulability, increased susceptibility to infections and hormonal variations. ${ }^{40}$

In our case, the patient was diagnosed with SC hemoglobinopathy through hemoglobin electrophoresis associated with peripheral blood smear evaluation, which showed the presence of target red blood cells. Compared to patients with SS hemoglobinopathy, patients with SC hemoglobinopathy present lower mortality and morbidity, with occurrence of less severe complications, as well as better obstetric and perinatal outcomes. ${ }^{39}$ However, complications including painful crises, preterm birth, pre-eclampsia and postpartum hemorrhage have been well documented in the literature for both $\mathrm{HbSS}$ and $\mathrm{HbSC}$. Although these complications occur less frequently in the HbSC disease, there were no statistically significant differences between the two genotypes. $^{38}$

Regarding pulmonary complications, a study carried out in Belo Horizonte, Minas Gerais (MG) showed that the main cause of maternal death was acute chest syndrome and that the risks among the carriers of the $\mathrm{HbSC}$ and $\mathrm{HbSS}$ subtypes were very similar. Thromboembolism and pulmonary 
infarction are also generally fatal complications occurring 9. mainly during the third trimester and puerperal period. ${ }^{40}$

Although prophylactic transfusions are commonly used in pregnant patients with hemoglobinopathies, there is still no evidence that this practice is superior to those performed on demand. ${ }^{39}$ Careful hematological and obstetric monitoring is therefore essential to ensure adequate management of pregnant and puerperal women with SC hemoglobinopathy, as well as early recognition of hemoglobinopathy complications and need of hemotransfusion. ${ }^{40}$

\section{CONCLUSION}

During pregnancy, women with the HbSC genotype may develop complications as severe as those presented by women with the HbSS genotype. However, the symptoms 14 presented by the patient at the end of gestation may also be confused with the VL condition, a diagnosis for which she presented two positive laboratory tests. In Brazil and in the world, there are few reports of $\mathrm{VL}$ in pregnant women, and of those available, the cases'origin is from regions known to be endemic to the disease, such as Tocantins. The use of Glucantime $^{\circledR}$ for treatment of $\mathrm{VL}$ in women who are breastfeeding is controversial. Therefore, we believe that the conduct of maintaining Glucantime ${ }^{\circledR}$ despite the bone marrow 17 aspirate negative result has scientific support. The direct search of the parasite in the bone marrow can be negative, while the polymerase chain reaction of this material would be the ideal diagnostic technique, since it presents greater sensitivity.

\section{REFERENCES}

1. Alencar JE, Neves J, Dietze R. Leishmaniose visceral (calazar). In Veronesi R, Focaccia R, Dietze R, eds. Tratado de Infectologia, 9th edn. São Paulo: Atheneu, 1997

2. Figueiró-Filho EA, Duarte G, El-Beitune P, Quintana SM, Maia TL. Visceral leishmaniasis (kala-azar) and pregnancy. Infectious 22. Diseases in Obstetrics and Gynecology. 2004;12(1):31-40.

3. Gontijo CM, Melo MN. Leishmaniose visceral no Brasil: quadro atual, desafios e perspectivas. Revista Brasileira de Epidemiologia. 2004;7:338-49.

4. Maia-Elkhoury AN, Alves WA, Sousa-Gomes ML, Sena JM, Luna EA. Visceral leishmaniasis in Brazil: trends and challenges. Cadernos de saude publica. 2008;24:2941-7.

5. AMARO RR. A relação entre o desmatamento e a incidência de 2 leishmaniose no município de Mesquita, RJ. Revista de Geografia, Meio Ambiente e Ensino. 2012 Jun 2;2(1):245-62.

6. Silva KB, Castro JG, Calabrese K, Seibert CS, do Nascimento GN, Mariano SM, Figueiredo BN, dos Santos MG. ANÁLISE ESPACIAL DA LEISHMANIOSE VISCERAL NO MUNICÍPIO DE PALMAS, TOCANTINS, BRASIL. Hygeia. 2017 Sep 1;13(25):18-29.

7. WORLD HEALTH ORGANIZATION (WHO). Diseases covered by NTD Department, 2017. http://www.who.int/neglected_diseases/diseases/en/). Acesso em: 08-01-2018

8. Reis LL, Balieiro AA, Fonseca FR, Gonçalves MJ. Changes in the epidemiology of visceral leishmaniasis in Brazil from 2001 to 2014. Revista da Sociedade Brasileira de Medicina Tropical. 2017 Sep;50(5):638-45.
Alvar J, Velez ID, Bern C, Herrero M, Desjeux P, Cano J, Jannin J, den Boer M, WHO Leishmaniasis Control Team. Leishmaniasis worldwide and global estimates of its incidence. PloS one. 2012 May 31;7(5):e35671.

10. Ministério da Saúde, Secretaria de Vigilância em Saúde. Manual de recomendações para diagnóstico, tratamento e acompanhamento de pacientes com co-infecção Leishmania-HIV. Brasília, DF, 2011.

11. Ministério da Saúde, Secretaria de Vigilância em Saúde. Coeficiente de incidência de Leishmaniose Visceral por 100.000 habitantes. Brasil, Grandes Regiões e Unidades Federadas. 1990 a 2015. Brasília, DF, 2017.

12. Jayme MS, Wanderlei $\mathrm{CL}$, Castro JG. Perfil epidemiológico dos casos de Leishmaniose Visceral em Palmas, Tocantins no período de 2007-2014. Revista de Patologia do Tocantins. 2016 Mar 18;3(1):63-71.

13. Ministério da Saúde, Secretaria de Vigilância em Saúde. Guia de Vigilância em Saúde. Brasília, DF, 2016.

4. de Alvarenga DG, Escalda PM, da Costa AS, Monreal MT. Leishmaniose visceral: estudo retrospectivo de fatores associados à letalidade. Revista da Sociedade Brasileira de Medicina Tropical. 2010 Mar;43(2):194-7.

15. Filho EA, Uehara SN, de Almeida Senefonte FR, Lopes AH, Duarte G, El Beitune P. Leishmaniose visceral e gestação: relato de caso. Rev Bras Ginecol Obstet. 2005;27(2):92-7.

16. Caldas AJ, Costa JM, Gama ME, Ramos EA, Barral A. Visceral leishmaniasis in pregnancy: a case report. Acta tropica. $2003 \mathrm{Sep}$ 1;88(1):39-43.

7. Viana RB, Neiva CL, Dias AF, Souza EJ, Pádua PM. Felty's syndrome and Kala-azar: a challenge for the rheumatologist. Revista brasileira de reumatologia. 2010 Dec;50(6):710-3.

18. Sundar S, Rai M. 2002. Diagnóstico laboratorial da leishmaniose visceral . Clin. Diagn. Laboratório Immunol. 9 : 951-958

19. Badaro $R$, Benson $D$, Eulalio $M C$, Freire $M$, Cunha $S$, Netto $E M$, Pedral-Sampaio D, Madureira C, Burns JM, Rough Houghton, David JR, Reed SG. 1996. rK39: um antígeno clonado de Leishmania chagasi que prediz a leishmaniose visceral ativa.J. Infect. Dis. 173 : 758-761

20. Scott JM, Shreffler WG, Ghalib HW, el Asad A, Siddig M, Badaro R, Reed SG. 1991. Um teste diagnóstico rápido e simples para leishmaniose visceral ativa. Sou. J. Trop. Med. Hyg. 44 : 272-277

21. Sinha R, Sehgal S. 1994. Avaliação comparativa de testes sorológicos em calazar indiano . J. Trop. Med. Hyg. 97 : 333-340

22. Zijlstra EE, Ali MS, el-Hassan AM, el-Toum IA, Satti M, Ghalib HW, Kager PA. 1992. Kala-azar: estudo comparativo dos métodos parasitológicos e teste de aglutinação direta no diagnóstico. Trans. R. Soc. Trop. Med. Hyg. 86 : 505-507

23. Nuzum E, F Branco, III, Thakur C, Dietze R, Salários J, Grogl M, Berman J. 1995. Diagnóstico da leishmaniose visceral sintomática pelo uso da reação em cadeia da polimerase no sangue do paciente . J. Infect. Dis. $171:$ : 751-754

24. Piarroux R, Gambarelli F, Dumon H, M Fontes, Dunan S, Maria C, Toga B, Quilici M. 1994.Comparação de PCR com o exame direto de aspiração de medula óssea, mielocultura e sorologia para o diagnóstico de leishmaniose visceral em imunocomprometidos pacientes . J. Clin. Microbiol. 32 : 746-749

25. Deborggraeve S, M. Boelaert, Rijal S, D. De Doncker, Dujardin JC, Herdewijn P, Buscher P. 2008. Acurácia diagnóstica de uma nova PCR de Leishmania para leishmaniose visceral clínica no Nepal e seu papel no diagnóstico da doença. Trop. Med. Int. Saúde 13 : 1378-1383

26. el Harith A, Kolk AH, Leeuwenburg J, Muigai R, Huigen E, Jelsma T, Kager PA. 1988. Melhoria do teste de aglutinação direta para estudos de campo da leishmaniose visceral.J. Clin. Microbiol. 26 : 1321-1325

27. Harith AE, Kolk AH, Kager PA, Leeuwenburg J, Muigai R, Kiugu S, Laarman JJ. 1986. Um teste simples e econômico de aglutinação 
direta para sorodiagnóstico e estudos seroepidemiológicos da leishmaniose visceral . Trans. R. Soc. Trop. Med. Hyg. 80 : 583-586

28. Peruhype-Magalhães $V$, Machado-de-Assis TS, Rabello A. Use of the Kala-Azar Detect ${ }^{\circledast}$ and IT-LEISH ${ }^{\circledR}$ rapid tests for the diagnosis of visceral leishmaniasis in Brazil. Memórias do Instituto Oswaldo Cruz. 2012 Nov;107(7):951-2.

29. Silveira LJ, Rocha TJ, Ribeiro SA, Pedrosa CM. Historical series of patients with visceral leishmaniasis treated with meglumine antimoniate in a hospital for Tropical Diseases, Maceió-AL, Brazil. Revista do Instituto de Medicina Tropical de São Paulo. 2015 Feb;57(1):33-8.

30. Tato LP, Izquierdo EL, Martín SG, Lobato ES, Esteban CG, GarcíaBermejo I, Amador JR. Diagnóstico y tratamiento de la leishmaniasis visceral infantil. InAnales de Pediatría 2010 May 1 (Vol. 72, No. 5, pp. 347-351). Elsevier Doyma.

31. Zougaghi L, Moutaj R, Chabaa L, Agoumi A. Infantile visceral Leishmaniasis: epidemiological, clinical and biological characteristics. About 93 case reports in the children hospital of Rabat. Archives de pediatrie: organe officiel de la Societe francaise de pediatrie. 2009 Nov;16(11):1513-8.

32. Sanofi-Aventis Pharma. Drug description leaflet of Glucantime ${ }^{\circledR}$.

33. Ministério da Saúde, Secretaria de Vigilância em Saúde. Manual de Vigilância e Controle da Leishmaniose Visceral. Brasília, DF, 2006.

34. Romero Gustavo Adolfo Sierra, Flores Érico Marlon de Moraes, Noronha Elza Ferreira, Macêdo Vanize de Oliveira. High frequency of skin reactions in patients with leishmaniasis treated with meglumine antimoniate contaminated with heavy metals: a comparative approach using historical controls. Mem. Inst. Oswaldo Cruz [Internet]. 2003 Jan [cited 2018 Aug 25] ; 98( 1 ): 145-149.

35. de Freitas PF, Borges RR, Leal BH, Gonçalves MN, da Silva AM, Moura FJ, Sampaio RN, Veiga JP. Avaliação do eletrocardiograma de pacientes com leishmaniose tegumentar americana tratados com antimonial pentavalente (Glucantime ${ }^{\circledR}$ ). Revista de Patologia Tropical. 2014;43(4):405-11.

36. Matoussi N, Ameur HB, Amor SB, Fitouri Z, Becher SB. Toxicité cardiaque de l'antimoniate de méglumine (Glucantime ${ }^{\circledR}$ ). À propos d'une observation. Médecine et maladies infectieuses. 2007 Dec 1;37:S257-9.

37. Sampaio RN, Martins Netto E, Faria EA, Sampaio JH, Freitas LC, Marsden PD. Morte súbita causada por glucantime. An Bras Dermatol. 1988;63(1):35-7.

38. Rezai S, Cavallo G, Gottimukkala S, Mercado R, Henderson CE. Dual Case Report of Hemoglobin SC Disease in Pregnancy. Obstet Gynecol Int J. 2016;4(3):00105.

39. Benites BD, Benevides TC, Valente IS, Marques Jr JF, Gilli SC, Saad ST. The effects of exchange transfusion for prevention of complications during pregnancy of sickle hemoglobin C disease patients. Transfusion. 2016 Jan;56(1):119-24.

40. Resende Cardoso PS, de Aguiar LP, Amélia R, Viana MB. Clinical complications in pregnant women with sickle cell disease: prospective study of factors predicting maternal death or near miss. Revista Brasileira de Hematologia e Hemoterapia. 2014 Jul 1;36(4):256-63.

41. Jwa SC, Fujiwara T, Yamanobe $Y$, Kozuka K, Sago H. Changes in maternal hemoglobin during pregnancy and birth outcomes. BMC pregnancy and childbirth. 2015 Dec;15(1):80. 